\title{
Assessment of the experimental infection by Echinostoma paraensei (Lie \& Basch, 1967) (Trematoda: Echinostomatidae) in two Biomphalaria tenagophila (D'Orbigny, 1835) (Gastropoda: Planorbidae) isolates resistant and susceptible to Schistosoma mansoni (Sambon, 1907) (Trematoda: Schistosomatidae)
}

\author{
Michele Maria dos Santos ${ }^{1}$ \\ Juberlan Silva Garcia ${ }^{1}$ \\ Raquel de Oliveira Simões ${ }^{1}$ \\ Samaly dos Santos Souza ${ }^{2}$ \\ Paulo Marcos Zech Coelho ${ }^{3}$ \\ Zilton de Araújo Andrade ${ }^{2}$ \\ Arnaldo Maldonado Júnior ${ }^{1 *}$

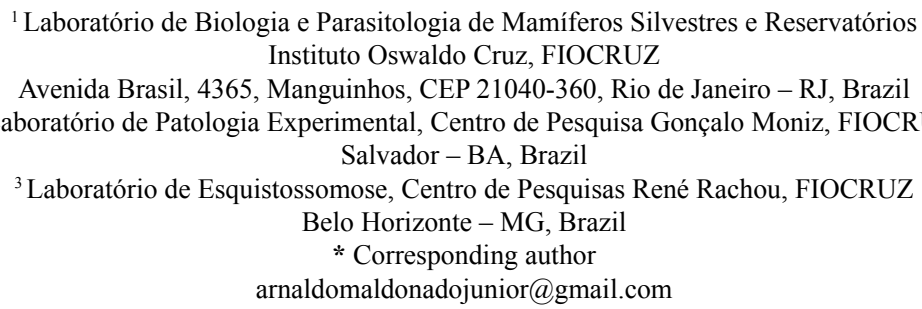

${ }^{1}$ Laboratório de Biologia e Parasitologia de Mamíferos Silvestres e Reservatórios Instituto Oswaldo Cruz, FIOCRUZ

Avenida Brasil, 4365, Manguinhos, CEP 21040-360, Rio de Janeiro - RJ, Brazil Salvador - BA, Brazil

${ }^{3}$ Laboratório de Esquistossomose, Centro de Pesquisas René Rachou, FIOCRUZ Belo Horizonte - MG, Brazil

* Corresponding author

arnaldomaldonadojunior@gmail.com \\ ${ }^{2}$ Laboratório de Patologia Experimental, Centro de Pesquisa Gonçalo Moniz, FIOCRUZ
}

Submetido em 05/07/2016

Aceito para publicação em 02/02/2017

\section{Resumo}

Avaliação da infecção experimental por Echinostoma paraensei (Lie \& Basch, 1967) (Trematoda: Echinostomatidae) em duas linhagens de Biomphalaria tenagophila (D'Orbigny, 1835) (Gastropoda: Planorbidae) resistentes e suscetíveis ao Schistosoma mansoni (Sambon, 1907) (Trematoda: Schistosomatidae). Diferentes linhagens de Biomphalaria tenagophila mostram amplo espectro de compatibilidade para Schistosoma mansoni, que vai desde refratária a altamente suscetível. O objetivo deste estudo foi verificar o padrão de compatibilidade de duas linhagens geográficas de B. tenagophila, resistentes e suscetíveis ao $S$. mansoni, para a infecção com Echinostoma paraensei. Foram utilizadas diferentes cargas miracidianas onde se avaliou a mortalidade, características histopatológicas e emissão de cercárias. Observou-se correlação entre o número de miracídios e a taxa de infecção em B. tenagophila (TAIM). Não houve correlação entre a carga de miracídios utilizados e a emissão cercariana em ambas as linhagens de B. tenagophila. Biomphalaria tenagophila $(\mathrm{SJC})$ mostrou pouca susceptibilidade à infecção por $E$. paraensei. Os resultados demonstraram diferentes graus de compatibilidade das duas linhagens de B. tenagophila ao E. paraensei, podendo contribuir para os estudos de relação parasito-hospedeiro.

Palavras-chaves: Histopatologia; Linhagens de moluscos; Relação parasito-hospedeiro 


\section{Abstract}

Different isolates of Biomphalaria tenagophila show a large spectrum of compatibility to the trematode Schistosoma mansoni, ranging from entirely refractory to highly susceptible. The aim of this study was to verify the pattern of compatibility of two B. tenagophila geographical isolates, resistant and susceptible to $S$. mansoni, when infected with Echinostoma paraensei. The snails were exposed to different numbers of miracidia, and mortality, histopathological characteristics and the number of cercariae released were evaluated. A correlation between the number of miracidia and the infectivity rate of $B$. tenagophila (TAIM) was observed. There was no correlation between the number of miracidia used and the number of cercariae released for both $B$. tenagophila isolates. Biomphalaria tenagophila (SJC) showed little susceptibility to the E. paraensei infection. The results demonstrate different degrees of compatibility for the two B. tenagophila isolates when infected with E. paraensei, and may contribute to studies about host-parasite relationships.

Key words: Histopathogy; Host-parasite relationships; Snail isolates

\section{Introduction}

The snail Biomphalaria tenagophila has a wide spectrum of compatibility to Schistosoma mansoni and Echinostoma paraensei infections, ranging from refractory to highly susceptible. Moreover, different isolates of snail species can show a heterogeneous pattern to a parasite species infection (COELHO et al., 2004; ROSA et al., 2006; GARCIA et al., 2010; NACIFPIMENTA et al., 2012).

Parasites can influence a snail host population in different ways, for example, by affecting fertility by destroying gonadal tissues or depleting the stock of nutritional resources, like galactogen, or through mortality during development (SORENSEN; MINCHELA, 2001). These effects can also be observed from physio-pathological alterations induced by parasites during the course of infection (PINHEIRO et al., 2009). Furthermore, the infectivity of snails can be influenced by age, geographic origin and abiotic variables (ANDERSON et al., 1982; ODONGOAGINYA et al., 2008).

Studies about host-parasite relationships have indicated new mechanisms where some snail isolates are refractory or susceptible to parasitism (PERRIN et al., 2013). To evade or subvert the internal defense system of the snail intermediate hosts, and guarantee their development, digenetic trematodes adopt different strategies, such as mimicking the internal host environment or reducing the hemocyte or humoral response (LOKER; ADEMA, 1995).
Recently, epigenetic mechanisms have been shown to play a role in modulating snail host susceptibility to helminth infection. The changes provoked by these mechanisms, such as stress, result in a selective pressure that shapes parasite survival or destruction in the host (ITTIPRASERT; KNIGHT, 2012; KNIGHT et al., 2016).

Therefore, the aim of this study was to evaluate the pattern of compatibility of two geographic isolates of B. tenagophila (refractory and susceptible to $S$. mansoni) to infections by the trematode E. paraense $i$ through exposure to different numbers of miracidia. Additionally, pathological features during the patent period are reported.

\section{Material and Methods}

\section{Snails and parasite}

The specimens of $B$. tenagophila, isolated from the Taim Reserve (TAIM - refractory to $S$. mansoni) in Rio Grande do Sul State and São José dos Campos (SJC - susceptible to S. mansoni) in São Paulo State, were obtained from the colony maintained by the Malacology Laboratory of the Oswaldo Cruz Institute (FIOCRUZ). The miracidia of $E$. paraensei were obtained from the Laboratory for Biology and Parasitology of Wild Mammal Reservoirs (LABPMR) (MALDONADO JR. et al., 2001a; 2001b). The life cycle of E. paraensei was maintained in accordance with the rules of the Committee on Ethics in the Use of Animals of FIOCRUZ (permit LW-0020/10). 


\section{Experimental design}

The snails used in the tests had an average shell diameter of $8 \mathrm{~mm}$ and were two months old. Five groups were formed from each isolate: B. tenagophila (TAIM), refractory to $S$. mansoni infection; and B. tenagophila (SJC), susceptible to $S$. mansoni. Each group was composed of ten snails for a total of 100 specimens.

The snails of each group were individually exposed to $10,25,50$ or 100 miracidia of E. paraensei under a 60-watt light overnight (SAPP; LOKER, 2000). An unexposed group of snails was also made. Subsequently, each snail was maintained individually in an aquarium containing $250 \mathrm{~mL}$ of dechlorinated water and autoclaved clay. They were fed with lettuce (Lactuca sativa) ad libitum and kept at a temperature between $26 \pm 1^{\circ} \mathrm{C}$ and photoperiod of $12 \mathrm{~h}$ (COSTA et al., 2004).

\section{Infectivity assessment and mortality rates}

Once a week, the snails were individually placed in Petri dishes with $3 \mathrm{~mL}$ of dechlorinated water under a 60 -watt light for $3 \mathrm{~h}$ to stimulate cercarial release. The released cercariae were counted from the third week after exposure and, following Maldonado Jr. et al. (2001a), the average number of larvae released was calculated by the number of released larvae divided by the number of snails releasing cercariae. Based on Muñoz-Antoli et al. (2007), the mortality rates were estimated weekly for nine weeks.

\section{Histopathological analysis}

Additionally, ten specimens of each B. tenagophila isolate were exposed individually to $50 \mathrm{E}$. paraensei miracidia, in order to verify the pathological features during the patent period. Thirty-five days after exposure, the snails were anesthetized by dipping them in a solution of $0.5 \%$ sodium pentobarbital (Hypnol) and removing them from the shells. The soft parts were fixed in Millonig's solution. The material was dehydrated in an alcohol series, clarified in xylol, imbedded in paraffin, cut into 5 micrometer sections and stained with hematoxylin and eosin (TOLOSA et al., 2003). The sections were photographed using a Zeiss Axioscop 2 microscope couple to a JVC TK-128OU camera.

\section{Statistical analysis}

The data were expressed as an average \pm standard error and a one-way ANOVA was carried out using the Statistica 7.0 software package. A Tukey HSD post-test was used to compare infectivity and cercarial release among the groups exposed to different numbers of miracidia. The chi-square test was applied to compare the mortality values. For all the statistical tests, $P<0.05$ was considered significant.

\section{Results}

\section{Infectivity rate}

The infectivity was dependent on the miracidial number, with $B$. tenagophila (TAIM) showing 20\% infection after exposure to 25 miracidia, followed by $30 \%$ and $90 \%$ after exposure to 50 and 100 miracidia, respectively. Biomphalaria tenagophila (SJC) specimens were more refractory to $E$. paraensei infection, with only a $10 \%$ infectivity rate in the groups exposed to 50 or 100 miracidia. The specimens infected with 25 miracidia did not release cercariae. However, these differences were not significant $(P>0.05)$.

\section{Cercarial release}

All the infected $B$. tenagophila (TAIM) specimens in the groups exposed to 25, 50 and 100 miracidia released cercariae until the ninth week of infection, starting at the fourth week post exposure (Figure 1). In contrast, the infected B. tenagophila (SJC) specimens exposed to 50 miracidia released cercariae in the fourth week and the group exposed to 100 miracidia released cercariae in the third week after exposure (Figure 1).

The number of cercariae released from $B$. tenagophila (TAIM) showed a tendency to increase from the fourth to the ninth week after exposure in the groups exposed to 25, 50 and 100 miracidia. In contrast, B. tenagophila (SJC) released cercariae only in the third and fourth weeks after exposure to 50 and 100 miracidia, respectively, and died after this period (Figure 1). 
FIGURE 1: Average number of cercariae released from snails exposed to 25 miracidia (A), 50 miracidia (B), and 100 miracidia (C) of Echinostoma paraensei (Biomphalaria tenagophila TAIM and SJC isolates).

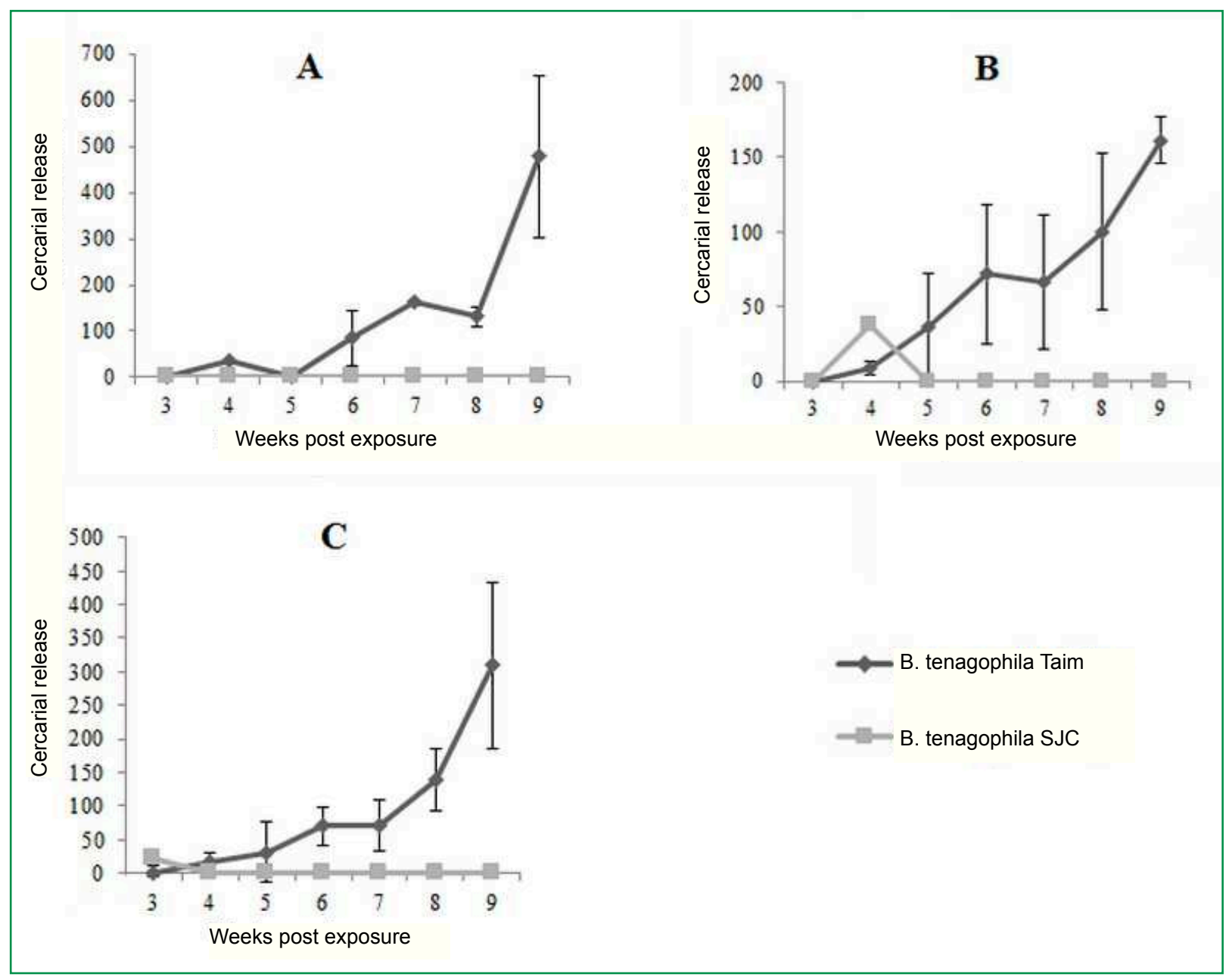

\section{Mortality rate}

The B. tenagophila (TAIM) specimens presented the lowest mortality rate. No mortality was observed for the groups exposed to 10,25 and 100 miracidia and the unexposed snails, while the group exposed to 50 miracidia showed only $20 \%$ mortality in the pre-patent period.

The mortality of B. tenagophila (SJC) occurred only in the groups exposed to higher numbers of miracidia (50 and 100 miracidia) during the pre-patent period, showing $10 \%$ mortality in both groups. The highest mortality rates were observed immediately after the start of the patent period, reaching $60 \%$ at the fifth week for these groups. Moreover, mortality occurred whether or not the snails released cercariae. There was no significant difference in mortality when comparing the groups exposed to different numbers of miracidia.

\section{Histopathological aspects}

Histological sections of $B$. tenagophila (TAIM) five weeks after exposure to $E$. paraensei revealed parasites in the pericardial sac and in the digestive gland but with no tissue reactions or hemocyte presence in these organs. However, a focal accumulation of hemocytes surrounding parasites was observed in the ovotestis region, where they provoked partial tissue damage (Figure 2). No tissue reactions or parasites were observed in the kidneys. 
FIGURE 2: Histological sections of Biomphalaria tenagophila (TAIM) 35 days after exposure to Echinostoma paraensei. Figures 2A and 2B - Heart region (h): Agglomerate of sporocysts (arrows) in the pericardial sac and next to the heart region. Figure 2C Digestive gland: Few sporocysts were present, most of which were in a degeneration stage (arrows). Figure 2D - Ovotestis: Hemocyte reaction present, causing partial tissue damage. Presence of sporocysts in a degeneration state (arrows) surrounded by the hemocyte reaction and destroyed residual cells ${ }^{(*)}$. Optical microscopy, stained with hematoxylin \& eosin, X 20 (2A; 2B), X 40 (2C), X 100 (2D).
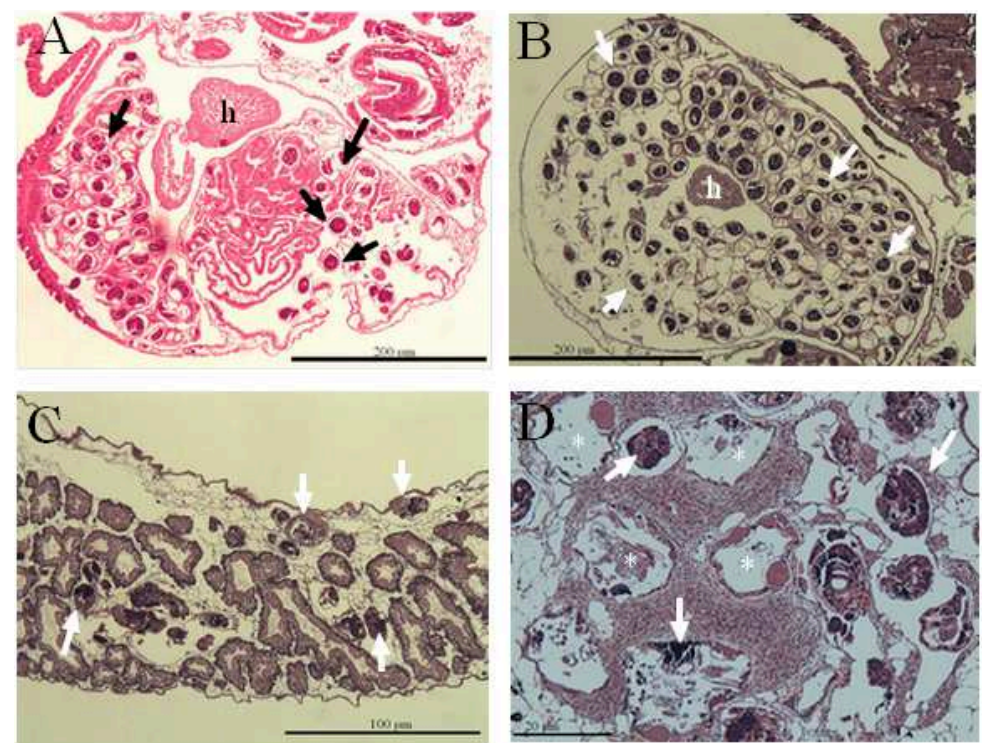

In B. tenagophila (SJC), few hemocytes were

reaction). Few remaining cells of the original structural observed in the pericardial sac even in the absence of parasites in this region. Near the kidney, a parasite was observed encapsulated by hemocytes (focal tissue

tissue were observed in the ovotestis and only some hemocyte infiltrates with no parasites were observed (Figure 3). No parasites or tissue reactions were observed in the digestive glands.

FIGURE 3: Histological sections of Biomphalaria tenagophila (SJC) 35 days after exposure to Echinostoma paraensei. Figure 3A - A few hemocytes (arrows) were observed in the central region of the heart (h). Figures 3B and 3C - A large accumulation of hemocytes and an encapsulation reaction (arrow) were observed between the heart and kidney region. Figure 3D - A few cells of the original structural tissue remained $(*)$. Presence of hemocyte reactions on the edge of the ovotestis tissue (arrows). Optical microscopy, stained with hematoxylin \& eosin, X 20 (2A; 2B; 2C), X 40 (2D).
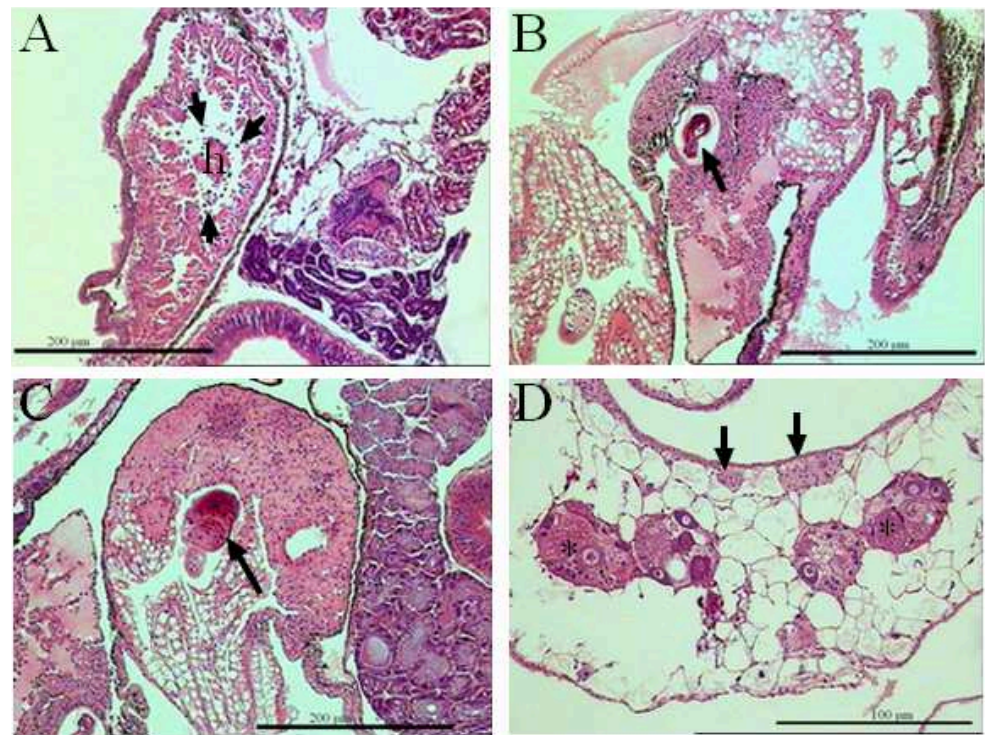


\section{Discussion}

Biomphalaria tenagophila TAIM (refractory to $S$. mansoni) presented higher infectivity rates to $E$. paraensei than SJC (susceptible). Reactive oxygen is a factor involved in refractoriness of B. glabrata to infection by $S$. mansoni (MONÉ et al., 2011). Unlike what was expected, the results showed that these digeneans act in different ways to evade the host defense mechanisms (LAFFERTY; SHAW, 2013). Corroborating these data, Garcia et al. (2010) showed that even with a prior infection by E. paraensei, B. tenagophila (TAIM) maintained refractoriness when exposed to $S$. mansoni. In fact, it has been shown that immune suppression (or interference) is a key function in the BiomphalariaEchinostoma relationship, allowing the parasite to evade attack of humoral factors such as FREPs (ADEMA et al., 2013).

In this study, we observed a direct relationship between the number of miracidia applied and the infectivity rate of $B$. tenagophila (TAIM). The same correlation was also observed between the number of $E$. paraensei miracidia and infectivity rate in $B$. glabrata (SU) and Lymnaea columella (MALDONADO JR. et al., 2001a; PINHEIRO et al., 2009). In both isolates of B. tenagophila, the infectivity rate was dependent on the number of miracidia exposed to the snail. However, the infection only occurred at the higher miracidial doses in B. tenagophila (SJC), indicating that this species is less susceptible to E. paraensei infection. These results are in accordance to Knight et al. (2016), who proposed that the parasite may orchestrate the behavior of specific genes, specifically HSP 70, to its advantage. In general, the number of miracidia used are a determining factor for infectivity. Some authors have demonstrated that even though a large number of miracidia achieves total penetration, not all of the miracidia develop, which may be due to biotic stress (DREYFUSS et al., 1999). This last mechanism may be involved in a demand on the snails for more energy, resulting in an exacerbated immune response and death.

In this study, the number of cercariae released was not influenced by the number of miracidia in both B. tenagohila (TAIM and SJC) specimens, which is in agreement with Dreyfuss et al. (1999). Limited reproductive capacity of the parasite may have occurred in the present study, which was possibly influenced by factors such as nutrient availability and physical space for cercariogenesis (TUNHOLI ET AL., 2011a; 2011b).

The infection was also a determining factor of the mortality observed in both snail isolates, but it was higher in B. tenagophila (SJC). Parasites can influence host survival in different ways. When mortality occurs soon after exposure, it has been associated with adaptive effects, while when mortality occurs afterward it probably indicates excessive energy requirement or tissue damage provoked by the parasite (BAYNE; LOKER, 1987).

Maldonado Jr. et al. (2001a) observed that in $B$. glabrata, Physa marmorata and L. columella infected by E. paraensei, mortality occurred throughout the infection period. However, in L. columella the mortality occurred predominantly in the pre-patent period. The same pattern was observed by Muñoz-Antoli et al. (2007) for $B$. glabrata infected by $E$. friedi. However, in the present study, the survival of $B$. tenagophila (TAIM) was not influenced by the exposure to E. paraensei because there was no relation between the mortality rate and the number of miracidia used.

In the present study, unlike what occurs after exposure to $S$. mansoni miracidia, B. tenagophila (TAIM) was highly susceptible to $E$. paraensei infection, as indicated by the histopathological findings and the presence of several parasitic forms in development under inflammatory reaction only in the ovotestis. This fact agrees with another study where the pericardial sac, digestive gland and ovotestis were the sites most colonized by the parasite (BOMFIM et al., 2014). Therefore, for the E. paraensei infection, B. tenagophila (TAIM) developed a similar pathological pattern compared to B. glabrata isolates highly susceptible to infection by $S$. mansoni.

Moreover, B. tenagophila (SJC) showed little compatibility to $E$. paraensei infection, unlike what occurred during $S$. mansoni infection where this isolate showed moderate susceptibility. No parasites were found in the heart, but many hemocytes were observed, 
indicating recruitment to that site. In turn, there was severe reaction in the kidney region, consisting of both focal and diffuse tissue reactions. Some hemocyte proliferative foci were also seen in the ovotestis region.

In conclusion, the results demonstrate the compatibility of the two isolates of B. tenagophila to $E$. paraensei through infection with different numbers of miracidia, cercarial release, mortality and histopathological features. Moreover, they suggest that infection by $E$. paraensei represents a biotic stress that is expressed differently in the Biomphalaria isolates.

\section{Acknowledgements}

This study was supported by CAPES. We also thank Dr. Lygia dos Reis Corrêa, Paulo César and Heloísa Brandão, the Malacology Laboratory of the Oswaldo Cruz Institute (FIOCRUZ), and André Campos Santana and Camila dos Santos Lucio from the Laboratory for Biology and Parasitology of Wild Mammal Reservoirs of FIOCRUZ for the technical assistance.

\section{References}

ADEMA, E. M.; SAPP, K. K.; HERTEL, L. A.; LOKER, E. S. Immunobiology of the relationship of Echinostomes with snail intermediate hosts. In: FIRED, B.; GRACZYK T. K. (Ed.). Echinostomes as experimental models for biological research. New York: Springer Science \& Business Media, 2013. p. 149-174.

ANDERSON, R. M.; MERCER, J. G.; WILSON, R. A.; CARTER, N. P. Transmission of Schistosoma mansoni from man to snail: experimental studies of miracidial survival and infectivity in relation to larval age, water temperature, host size and host age. Parasitology, Cambridge, v. 85, n. 2, p. 339-360, 1982.

BAYNE, C. J.; LOKER, E. S. Survival within the snail host. In: ROLLINSON, D.; SIMPSON A. J. D. (Ed.). The biology of schistosomes: from genes to latrines. San Diego: Academic Press Ltd., 1987. p. 321-346.

BOMFIM, T. C. S.; MALDONADO JR., A.; TUNHOLI, V. M.; TUNHOLI-ALVES, V. M.; FARO, M. J.; MOTA, E. M.; SILVA, T. C. B.; PINHEIRO, J.; GARCIA, J. S. Biochemical and histopathological alterations in Biomphalaria glabrata due to co-infection by Angiostrongylus cantonensis and Echinostoma paraensei. Journal of Invertebrate Pathology, Riverside, v. 115, p. 80-85, 2014.

COElHO, P. M.; CARVALHO, O. S.; ANDRADE, Z. A.; MARTINS-SOUSA, R. L.; ROSA, F. M.; BARBOSA, L.; PEREIRA, C. A.; CALDEIRA, R. L.; JANNOTTI-PASSOS, L. K.; GODARD, A. L.; MOREIRA, L. A.; OLIVEIRA, G. C.; FRANCO, G. R.; TELES, H. M.; NEGRÃO-CORRÊA, D. Biomphalaria
tenagophila/Schistosoma mansoni interaction: premises for a new approach to biological control of schistosomiasis Memórias do Instituto Oswaldo Cruz, Rio de Janeiro, v. 99, n. 1, p. 109-111, 2004.

COSTA, M. J. F. S.; GRAULT, C. E.; CONFALONIERI, U. E. C. Comparative study and fertility of Biomphalaria glabrata (Say, 1818) and Biomphalaria straminea (Dunker, 1848) in a laboratory through self-fertilization and cross-fertilization. Revista do Instituto de Medicina Tropical de São Paulo, São Paulo, v. 46, n. 3, p. 157-163, 2004.

DREYFUSS, G.; VIGNOLES, P.; RONDELAUD, D.; VAREILLEMOREL, C. Fasciola hepatica: characteristics of infection in Lymnaea trunculata in relation to the number of miracidia at exposure. Experimental Parasitology, Amsterdam, v. 92, n. 1, p. 19-23, 1999.

GARCIA, J. S.; MALDONADO JR., A.; BIDAU, J.; CORREA, L. R.; LANFREDI, R. M.; COELHO, P. M. Z. Effect of early infection with Echinostoma paraensei on interaction Schistosoma mansoni with Biomphalaria glabrata and Biomphalaria tenagophila. Memórias do Instituto Oswaldo Cruz, Rio de Janeiro, v. 105, n. 4, p. 499-503, 2010.

ITTIPRASERT, W.; KNIGHT, M. Reversing the resistance phenotype of the Biomphalaria glabrata snail host Schistosoma mansoni infection by temperature modulation. Plos Pathogens, San Francisco, v. 8, n. 4, p. e1002677, 2012.

KNIGHT, M.; ITTIPRASERT, W.; ARICAN-GOKTAS H. D.; BRIDGER J. M. Epigenetic modulation, stress and plasticity in susceptibility of the snail host, Biomphalaria glabrata, to Schistosoma mansoni infection. International Journal for Parasitology, Amsterdam, v. 46, n. 7, p. 389-394, 2016.

LAFFERTY, K. D.; SHAW, J. C. Comparing mechanisms of host manipulation across host and parasite taxa. The Journal of Experimental Biology, Cambridge, v. 16, n. 1, p. 56-66, 2013.

LOKER, E. S.; ADEMA, C. M. Schistosomes, Echinostomes and snails: comparative immunobiology. Parasitology Today, Cambridge, v. 11, n. 3, p. 120-124, 1995.

MALDONADO JR., A.; LOKER, E. S.; MORGAN, J. A. T.; REY, L.; LANFREDI, R. M. Description of the adult worms of a new Brazilian strain of Echinostoma paraensei (Platyhelminthes: Digenea) from its natural vertebrate host Nectomys squamipes by light and scanning electron microscopy and molecular analysis. Parasitology Research, Heidelberg, v. 87, p. 840-848, $2001 \mathrm{a}$.

MALDONADO JR., A.; VIEIRA, G. O.; GARCIA, J. S.; REY, L.; LANFREDI, R. M. Biological aspects of a new strain of Echinostoma paraensei (Trematoda: Echinostomatidae): susceptibility of sympatric snails and the natural vertebrate host. Parasitology Research, Heidelberg, v. 87, p. 853-859, $2001 \mathrm{~b}$.

MONÉ, Y.; RIBOU, A. C.; COSSEAU, C.; DUVAL, D.; THÉRON, A.; MITTA, G.; GOURBAL, B. An example of molecular coevolution: reactive oxygen species (ROS) and ROS scavenger levels in Schistosoma mansoni/Biomphalaria glabrata interactions. International Journal for Parasitology, Amsterdam, v. 41, n. 7, p. 721-730, 2011.

MUÑOZ-ANTOLI, C; MARÍN, A.; TOLEDO, R.; ESTEBAN, J. G. Effect of Echinostoma friedi (Trematoda: Echinostomatidae) experimental infection on longevity, growth and fecundity of juvenile Radix peregra (Gastropoda: Lymnaeidae) and Biomphalaria 
glabrata (Gastropoda: Planorbidae) snails. Parasitology Research, Heidelberg, v. 101, n. 6, p. 1663-1670, 2007.

NACIF-PIMENTA, R.; MATTOS, A. C.; ORFANÓ, A. S.; BARBOSA, L.; PIMENTA, P. F.; COELHO, P. M. Schistosoma mansoni in susceptible and resistant snail strains Biomphalaria tenagophila: in vivo tissue response and in vitro hemocyte interactions. PLoS One, Cambridge, v. 7, n. 9, p. e45637, 2012.

ODONGO-AGINYA, E. I.; KIRONDE, F. K.; KABATEREINE, N. B.; KATEGERE, P.; KAZIBWE, F. Effect of seasonal rainfall and other environmental changes, on snail density and infection rates with Schistosoma mansoni fifteen years after the last snails' study in Kigungu, Entebbe, Uganda. East African Medical Journal, Nairobi, v. 85, n.11, p. 556-563, 2008.

PERRIN, C.; LEPESANT, J. M.; ROGER, E.; DUVAL, D.; FNEICH, S.; THUILLIER, V.; ALLIENE, J. F.; MITTA, G.; GRUNAU, C.; COSSEAU, C. Schistosoma mansoni mucin gene (SmPoMuc) expression: epigenetic control to shape adaptation to a new host. PLoS Pathogens, San Francisco, v. 9, n. 8, p. 1-14, 2013. PINHEIRO, J.; MALDONADO JÚNIOR, A.; LANFREDI, R. M. Physiological changes in Lymnaea columella (Say, 1817) (Mollusca, Gastropoda) in response to Echinostoma paraensei (Lie and Basch, 1967) (Trematoda: Echinostomatidae) infection. Parasitology Research, Heidelberg, v. 106, n. 1, p. 55-59, 2009.

ROSA, F. M.; GODARD, A. L.; NEGRÃO-CORREA, D.; RODRIGUES, H. A.; CARVALHO ODOS, S.; CALDEIRA, R. L.; TELES, H. M.; MACIEL, E.; JANNOTTI-PASSOS, L. K.; COELHO, P. M. Biomphalaria tenagophila: dynamics of populations of resistant and susceptible strains to Schistosoma mansoni, with or without pressure of the parasite. Memórias do Instituto Oswaldo Cruz, Rio de Janeiro, v. 101, n. 1, p. 247-251, 2006.
SAPP, K. K.; LOKER, E. S. Mechanisms underlying digeneansnail specificity: role of miracidial attachment and host plasma factors. Journal of Parasitology, Lawrence, v. 86, n. 5, p. 1012$1019,2000$.

SORENSEN, R. E.; MINCHELLA, D. J. Snail-trematode life history interactions: past trends and future directions. Parasitology, Cambridge, v. 123, n. 3, p. 3-18, 2001.

TOLOSA, E. M. C.; RODRIGUES, C. J., BEHMER, O. A.; NETO, A. G. F. Manual de técnicas para histologia. Normal e Patológica. 2 ed. Barueri: Manole, 2003. 331 p.

TUNHOLI, V. M.; LUSTRINO, D.; TUNHOLI-ALVES, V. M.; MELLO-SILVA, C. C.; MALDONADO JR., A; PINHEIRO, J.; RODRIGUES, M. L. Biochemical profile of Biomphalaria glabrata (Mollusca: Gastropoda) after infection by Echinostoma paraensei (Trematoda: Echinostomatidae). Parasitology Research, Heidelberg, v. 109, n. 3, p. 885-891, 2011a.

TUNHOLI, V. M.; LUSTRINO, D.; TUNHOLI-ALVES, V. M.; MELLO-SILVA, C. C.; MALDONADO JR., A; RODRIGUES, M. L.; PINHEIRO, J. Changes in the reproductive biology of Biomphalara glabrata infected with different doses of Echinostoma paraensei miracidia. Journal of Invertebrate Pathology, Riverside, v. 106, n. 2, p. 192-195, 2011 b. 